\title{
Prevalence and relationship between analgesic and alcohol pain amongst craftsmen in a South-East Nigerian community
}

\author{
Gabriel Omoniyi Ayeni ${ }^{1, ~ *}$, Oyewale Mayowa Morakinyo ${ }^{2}$, Oladire Olaniyi ${ }^{1}$, \\ Ayodele Teslim Onigbinde ${ }^{3}$, Oluwasegun AkindeleAyeni ${ }^{4}$ \\ ${ }^{1}$ Department of Physiotherapy, Federal Medical Centre, Owerri, Nigeria \\ ${ }^{2}$ Department of Public Health Technology, Federal University of Tech., Owerri, Nigeria \\ ${ }^{3}$ Dept of Medical Rehabilitation, Obafemi Awolowo University, Ile-Ife, Nigeria \\ ${ }^{4}$ Department of Mathematics (Statistics), University of Ibadan, Ibadan, Nigeria
}

\section{Email address:}

ayenco_2@yahoo.com (G. O. Ayeni),wahlemirax@gmail.com (O. M. Morakinyo),niyisco@yahoo.com (O. Olaniyi), ayotesonigbinde@yahoo.co.uk (A. T. Onigbinde), ayeniolusegun@gmail.com (O. A. Ayeni)

\section{To cite this article:}

Gabriel Ayeni, Oyewale Morakinyo, Oladire Olaniyi, Ayodele Onigbinde, Oluwasegun Ayeni. Prevalence and Relationship between Analgesic and Alcohol Consumption, Smoking Habit and Occurrence of Lowback Pain amongst Craftsmen in a South-East Nigerian Community. American Journal of Health Research. Special Issue: Supplementary Prescribing in Nigeria: A Needy Concept to Promote Clinical Physiotherapy Practice. Vol. 2, No. 5-1, 2014, pp. 45-49. doi: 10.11648/j.ajhr.s.2014020501.19

\begin{abstract}
Low back pain (LBP) is a major cause of disability with high economic and public health repercussions. The main objectives of this study were to determine the prevalence and relationship between analgesic and alcohol consumption, smoking and occurrence of lowback pain amongst craftsmen in Owerri, a South-East Nigerian community. A structured questionnaire was used to collect data on lifestyle and low back pain of 500 craftsmen. The data was analyzed using descriptive statistics of mean, percentage, frequency and inferential statistics of chi square; and multiple regressions. The result showed that the point prevalence for LBP was 34\%. The 3-month, 12-month and life time prevalence of LBP were $35.4 \%$ $57.4 \%$ and $69.0 \%$ respectively. Habits of analgesic consumption $(\mathrm{OR}=5.51 ; \mathrm{CI}=1.07-4.29 ; \mathrm{p}=0.048)$ and alcohol consumption $(\mathrm{OR}=2.53, \mathrm{CI}=1.47-4.38, \mathrm{p}<0.001)$ had significant association with low back pain. We concluded that the point prevalence for low back pain was $34 \%$. Also, LBP was associated with some selected lifestyle factors.
\end{abstract}

Keywords: Prevalence, Analgesic and Alcohol Consumption, Craftsmen, Epidemiology, Low Back Pain, Smoking

\section{Introduction}

Low back pain (LBP) being the most common musculoskeletal problem in the work place is a major cause of work- related disability [1,2]. It is associated with major costs in terms of health resource usage, worker disability and absenteeism [3]. Low back pain is one of the four major musculoskeletal conditions leading to disability [4].

The incidence of LBP has continued to increase in modern societies such as United Kingdom, United States and Canada [5] and developing nations. Reports have shown that craftsmen and or production workers in the factories represent a significant portion of the worker population with LBP. Sanya et al found point and 12-month prevalence among industrial workers in a south-west Nigeria city to be
$59.7 \%$ and $59.5 \%$ respectively [6]. Murtezani et al found annual prevalence of low back pain among industrial workers to be $63.6 \%$ [7]. According to the findings of the systematic review among African population, the most common population presenting with LBP are the workers $(48 \%)$ while scholars comprised $15 \%$ of the population [8]. It is predicted that the greatest increases in LBP will be in developing nations [9].

People with chronic low back pain also use an enormous amount of health care [10]. As a result of the increasing number of older people throughout the world and industrialization, the burden of LBP on the individual and society as a whole is expected to increase dramatically [11]. While not a disease, back pain is a major cause of disability, especially in areas where compensation systems take it into cognizance [12]. 
Broadly, the variables (risk factors) associated with nonspecific low back pain can be classified as individual, psychosocial, or occupational factors and more recently, genetic and bio-mechanical models have contributed to the understanding of the development of back disorders that present as back pain [12]. General preventive programs frequently focus on the recognized biomechanical factors, workload and organizational issues [13], with minimal effort at identifying and controlling the risk disposing lifestyle factors.

Currently, there is dearth of data on LBP prevalence and the association between selected lifestyle factors and occurrence of LBP among craftsmen in Owerri, a major city in the South-East Nigeria. These groups of workers, in this environment often bend/stoop/stand to work thus predisposed to having back pain and early identification of risk disposing lifestyle in this high risk population would make for appropriate preventive approach.

This study therefore assessed the LBP prevalence and association between selected lifestyle factors of regular analgesic consumption, alcohol consumption, smoking habit and the occurrence/persistence of low back pain amongst craftsmen in Owerri, South-East Nigeria.

\section{Methodology}

\subsection{Population}

Owerri- the capital city of Imo State consists of three Local Government Areas (Owerri Municipal, Owerri North and Owerri West). It currently has a population of about 400,000 people and is approximately 40 square miles (100 $\mathrm{km} 2$ ) in area. It is bordered by the Otamiri River to the east and the Nworie River to the south. It occupies the area lying between coordinates $5.484^{\circ} \mathrm{N}$ and $7.035^{\circ} \mathrm{E}$.

\subsection{Sample}

A total of 500 male and female craftsmen were participants in this study.

\subsection{Research Design}

The design of this study was a descriptive cross-sectional survey.

\subsection{Sampling Technique}

A multi stage sampling design was used to select the participants. The participants were craftsmen/workers and were randomly selected across the three local government areas in Owerri. They included welders and panel beaters, carpenters and furniture men, mechanic, local soap and oil millers, tailors and weavers.

\subsection{Instrument}

A structured questionnaire was used for the study. There are three sections. Section A focused on socio-demographic information such as age, marital status, educational level etc. Section B sought answer to question on LBP history such as present and past lowback pain history and section $\mathrm{C}$ focussed on selected lifestyle factors such as analgesic consumption, alcohol consumption and smoking habits of respondents.

The questionnaire was assessed for content and face validity at a physiotherapists' clinical seminar. It was also reviewed by two clinical researchers and two lecturers (one was an epidemiologist) who are knowledgeable in questionnaire design and development to ensure good face and content validity, with clear, unambiguous question.

\subsection{Inclusion and Exclusion Criteria}

Low back pain case in this study was defined as pain or discomfort in the low back area between twelfth rib and gluteal fold (lower $1 / 3$ of the back) with or without pain in one or both legs lasting one day or longer or strong enough to make the worker absent from work, in their life time. Participants with deformity, illness and obvious medical impairment were excluded.

\subsection{Procedure}

Informed consent was obtained from participants. Confidentiality of information was maintained throughout the study. This research was conducted in compliance with the Helsinki Declaration. The questionnaire was administered for participants by the main investigator and trained field research assistants.

\subsection{Data Analysis}

The data collected was manually sorted out, edited and coded. It was thereafter inputed into the computer for analysis. Data was analyzed using SPSS computer software version 17 (SPSS, Inc., Chicago, IL). Both descriptive statistics of mean, standard deviation, frequency and Inferential statistics of chi square and multiple regressions were used for the data analysis based on the conceptual model of relationship between risk disposing habits and low back pain. Statistical significance for association was tested using chi-square, with p-value set at 0.05 .

\section{Results}

The prevalence of LBP among the craftsmen/workers was presented in Figure 1. Point prevalence was found to be $34 \%$. The 3-month, 12-month and life time prevalence of LBP were $35.4 \% 57.4 \%$ and $69.0 \%$ respectively.

\subsection{Respondents' Lifestyle Factors and Occurrence of LBP}

The relationship between craftsmen analgesic consumption, alcohol consumption, smoking lifestyle_factors and occurrence of LBP is presented in Table 1. There was a significant relationship between smoking, alcohol consumption, analgesic consumption and occurrence of LBP $(\mathrm{p}<0.05)$. The lifestyle factors that have significant relationship with LBP occurrence were entered for multiple regression analyses. The findings of this analyses showed respondents who consumed alcohol were almost 3 times 
more likely to develop LBP independently $(\mathrm{OR}=2.53 ; \mathrm{CI}=$ $1.47-4.38 ; \mathrm{p}=0.001)$. Those who engaged in regular analgesic consumption were 5 times more likely to develop
LBP compared to those who $\operatorname{did} \operatorname{not}(\mathrm{OR}=5.51 ; \mathrm{CI}=1.07$ $4.29 ; \mathrm{p}=0.048$ ) (Table 2). Smoking habit showed significant but weak association with low back pain.

Table 1. Relationship between selected lifestyle factors and occurrence of low back pain

\begin{tabular}{llll}
\hline Variable & LBP Sufferers & No LBP & P- value \\
\hline Smoking & & & \\
No & $130(37.7)$ & $33(21.3)$ & $<0.001$ \\
Yes & $215(62.3)$ & $122(78.7)$ & \\
Alcohol consumption & & & \\
No & $229(66.4)$ & $57(36.8)$ & $<0.001$ \\
Yes & $116(33.6)$ & $98(63.2)$ & \\
Analgesic consumption & & $67(27.4)$ & 0.042 \\
No & $90(35.3$ & $178(72.6)$ & 34.864 \\
Yes & $165(64.7)$ & & 302 \\
\hline
\end{tabular}

Table 2. Odd ratio for low back pain in relation to selected lifestyle factors

\begin{tabular}{|c|c|c|c|c|c|}
\hline Variable & Frequency (n) & Prevalence (\%) & p-value & adj. OR* & $95 \%$ CI \\
\hline \multicolumn{6}{|l|}{ Smoking } \\
\hline No & 337 & 67.4 & & 1.00 & \\
\hline Yes & 163 & 32.6 & $<0.001$ & 1.12 & $0.61-2.05$ \\
\hline \multicolumn{6}{|c|}{ Alcohol consumption } \\
\hline No & 214 & 42.8 & & 1.00 & \\
\hline Yes & 286 & 57.2 & $<0.001$ & 2.53 & $1.47-4.38$ \\
\hline \multicolumn{6}{|c|}{ Analgesic consumption } \\
\hline Yes & 157 & 31.4 & 0.048 & 5.51 & $1.07-4.29$ \\
\hline
\end{tabular}

*Adjusted odd ratio (Adj. OR) obtained from multiple logistic regression (adjusted for age and sex): $\mathrm{CI}=\mathrm{Confidence}$ interval

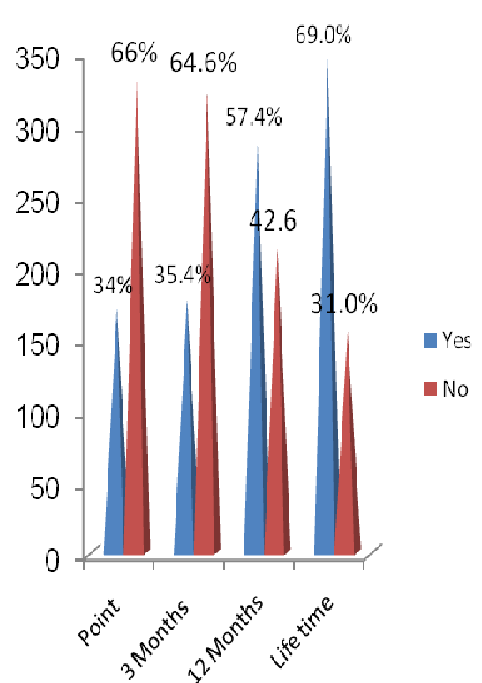

(Left triangle indicates the prevalence at a specific period of time)

Figure 1. Prevalence of lowback pain among craftsmen in Owerri, south east Nigeria

\section{Discussion}

Data on low back pain prevalence is important for effective public health policy and programme. We observed high prevalence of LBP among craftsmen among participants in this study. Sanya and Ogwumike reported that industrial workers in a major south west Nigeria city had point prevalence and 12-month prevalence of $57.5 \%$ and $57.1 \%$ respectively [14]. The mean point, 12-month and life-time prevalence of LBP among Africans according to the finding of systematic review by Louw et al was $32 \%, 50 \%$ and $62 \%$ among adults [8].

This finding negates any assumptions that LBP point prevalence is lower in the developing world than developed societies, as the range of LBP point prevalence among western societies is also reported to range between $12 \%$ and $33 \%[15,16]$.

We found significant associations between selected habits and occurrence of LBP. Those who consumed alcohol were about 3 times more likely to develop LBP. Al-Dubai et al found significant association between alcohol consumption and occurrence of LBP [17]. Miyamoto et al in their epidemiological study of low back pain and occupational risk factors among drivers also found significant association between LBP and alcohol consumption [18]. However, this study finding did not support the finding of a systematic review reported by Leboeurf-Yde which showed no significant association between alcohol consumption and LBP [19]. Tomita et al in their study of migrant seafood workers of Thai and Myammar also found no significant association between alcohol consumption and occurrence low back pain $(\mathrm{OR}<1)$ [20]. Sanya and Ogwumike found no significant association between alcohol consumption and lowback pain occurrence [14].

An association was found between frequent consumption of analgesic and occurrence of lowback pain. Non-steroidal anti-inflammatory drugs (NSAIDs) are of choice for acute pain management in musculoskeletal disorders (MSDs) but they are not without side effects [21]. NSAIDs are drugs of choice for acute pain management that may characterize musculoskeletal disorders including low back pain [22,23]. 
They are also commonly used in chronic musculoskeletal pain, although, the rationale remains controversial. There is evidence to support the use of NSAIDs in chronic spinal pain but this is based on evidence from trials lasting only few days [24-26]. From this study, those who consumed analgesic regularly were 5 times more likely to develop lowback pain compared to those who did not $(\mathrm{OR}=5.51 ; \mathrm{CI}=1.07-4.29$; $\mathrm{p}=0.048$ ). While the use of analgesic may be needful and beneficial in managing musculoskeletal pain at some point, indiscriminate and/or regular consumption should be discouraged. Frequently consuming analgesics tend to mask the feeling of pain thereby promoting the progression of the original cause of the pain without due attention for repair or possible curative intervention; curative intervention should be sought by lowback pain sufferers. A longitudinal exploratory study into the effect of analgesic consumption on lowback pain would be helpful in the future.

There was a significant but weak association between cigarette smoking and occurrence of LBP among the respondents. Smoking is the single most preventable cause of death and diseases in the United States [27]. Al-Dubai et al in their study of the prevalence and determinants of LBP among taxi drivers in Malaysia found significant association between smoking and occurrence of LBP [17]. Alkherayf and Agbi found LBP proportion to be higher among daily smokers $(23.5 \%)$ compared to $15.7 \%$ recorded among nonsmokers [28]. These studies evaluated for duration of smoking, age of the smoking population in relation to LBP. Leboeurf-Yde et al found association between smoking and LBP [29]. However, the finding of Tomita et al who studied risk factors for low back pain among seafood workers showed no significant association between smoking and LBP [18]. Sanya and Ogwumike also found no significant association between smoking and occurrence of LBP ( $p=$ 0.96) [14]. Jamison et al in their study of the relationship between cigarette smoking and LBP could not establish an association [30].

The cause-and-effect relationship could not be confirmed and information on the sequence of risk factor development is lacking and these might be limitation to this study. Other limitations include our inability to compare the effect of duration of lifestyle factors with the occurrence of lowback pain and dearth of previous research work in this region for comparism.

The findings of this study showed the necessity of preventive measure focusing on LBP and health education on good lifestyle such as avoiding indiscriminate use of analgesic and minimizing consumption of alcohol and smoking. Further prospective study will be beneficial. Future study may consider the effect of duration of the lifestyle factors among the craftsmen to the occurrence of lowback pain.

\section{Conclusions}

The findings of this study showed association between some selected lifestyle factors of craftsmen and occurrence of low back pain.

\section{Acknowledgements}

The authors thank the various craftsmen groups who allowed their members to participate in the study. We thank Mrs Elizabeth A. Ayeni for her assistance in proof reading this manuscript.

\section{References}

[1] Omokhodion FO, Sanya AO (2003). Risk factors for low back pain in the office workers. J. Occup. Med; 53: 287-289

[2] Cunninghan C, Doody C and Blake C (2008). Managing lowback pain: knowledge and attitude of hospital manager. J. Occup. Med; 258: 282-288

[3] Maniadakis N, Gray A (2000). The economic burden of back pain in the UK. Pain; 84: 95-103

[4] Woolf A, Pfleger B (2003). Burden of major musculoskeletal conditions. Bull World Health Organ; 81(9): 646-656

[5] Cole AJ, Heithoff KB, Herzog RJ (2003). The lumbar spine: imaging option. In: Cole AJ., Herring SA, eds. The lowback pain hand book: a guide for practicing clinician. 2nd ed. Philadelphia PA, USA: Hanley and Belfus. pp 219-262

[6] Sanya AO, Omokhodion FO, Ogwumike OO (2005). Risk factors for low back pain among hospital workers in Ibadan, Oyo State, Nigeria. J. Nig. Soc. Physioth; 15(2): 31-34

[7] Murtezani A, Ibraimi Z, Sllamniku S, Osmani T, Sherifi S (2012). Prevalence and risk factors for low back pain in industrial workers. Folia Med (Plovdiv). 53 (3): 68-74

[8] Louw QA, Morris LD, Grimmer-Somers K (2007). The Prevalence of low back pain in Africa: A systematic review. BMC Musculoskeletal Disorders; 8:105

[9] World Health Organization (2003). Scientific Group on the Burden of Musculoskeletal Conditions of the Start of the New Millennium. The burden of musculoskeletal conditions at the start of the new millennium. World Health Organ Technical Report Series 2003, 919: 1-218

[10] Freburger JK, Holmes GM, Agans RP, Jackman AM, Darter J.D, Wallace AS, Castel LD, Kalsbeek WD, Carey TS (2009). The rising prevalence of chronic low back pain. Arch. Intern. Med.; 169(3): 251-258

[11] Stewart GS, Wang B, Bignell CR, Taylor AM, Elledge SJ (2003). MDC1 is a mediator of the mammalian DNA damage checkpoint. Nature; 421: 961-966

[12] Maneka NJ, MacGregorb AJ (2005). Epidemiology of back disorders: prevalence, risk factors, and prognosis. Current Opinion in Rheumatology; 17:134-140

[13] Vieira ER, Kumar S, Narayan Y (2008). Smoking, no-exercise, overweight and low back disorder in welders and nurses. Int J. Ind. Ergs; 38(2): 143-149

[14] Sanya AO, Ogwumike OO (2005). Low back pain prevalence amongst Industrial workers in the private sector in Oyo State, Nigeria. Afr. J. Med. and Med. Sc.; 34(3): 245-9 
[15] Walker B (2000): The Prevalence of Low Back Pain: A Systematic Review of the Literature from 1966 to 1998. Journal of Spinal Disorders; 13(3):205-217.

[16] van Vuuren B, Zinzen E, van Heerden H, Becker P, Meeusen R (2005). Psychosocial Factors related to lower back problems in a South African Manganese Industry. Journal of Occupational Rehabilitation; 15(2):215-225.

[17] Al-Dubai SR, Qureshi AM, Ismail NH, Rampal KG (2012). Prevalence and determinants of lowback pain among taxi driver in Malaysia: a cross sectional study. J. Adv Med Res; 2(4): 129-143

[18] Miyamoto M, Konno S, Gembun Y, Liu X, Minami K, Ito H (2008). Epidemiological study of lowback pain and occupational risk factors among taxi drivers. Ind. Health; 46 (2):112-117

[19] Leboeuf-Yde C (2000). Alcohol and lowback pain: a systematic literature review. J.Mani. Physio. Ther; 23: 343-6

[20] Tomita S, Arphorn S, Muto T, Koetkhalai K, Naing S, Chaikittiporn C (2010). Prevalence and risk factors of lowback pain among Thai and Myammar migrant seafood processing factory workers in SamortSarkon Province, Thailand. Ind. Health, 48: 283-291

[21] Onigbinde AT, M'Kumbuzi V, Olaogun MO, Afolabi JO, Nondwe BM, Manie S, Tarimo N, Mukoka G (2014). Side Effects of Non-Steroidal Anti-Inflammatory Drugs: The Experience of Patients with Musculoskeletal Disorders. American Journal of Health Research; 2 (4):106-112. doi: 10.11648/j.ajhr.20140204.11

[22] Schnitzer TJ, Ferraro A, Hunsche E (2004). A comprehensive review of clinical trials on the efficacy and safety of drugs for the treatment of low back pain. J Pain Symptom Manage; 28:72-95.

[23] Ekman EF, Koman LA (2005). Acute pain following musculoskeletal injuries and orthopedic surgery: mechanisms and management. Instr Course Lect; 54:21-33.

[24] Hickey RF (1982). Chronic low back pain: a comparison of diflunisal with paracetamol. NZ Med J; 95:312-4.

[25] Videman T, Osterman K (1984). Double-blind parallel study of piroxicam versus indomethacin in the treatment of low back pain. Ann Clin Res; 16:156-60.

[26] Berry H,Bloom B, Hamilton, EB (1982). Naproxen sodium, diflunisal, and placebo in the treatment of chronic back pain. Ann Rheum Dis; 41:129-32.

[27] Klesges RC, ZbiwoskiSM, Lando HA (1998). The relationship between smoking and body weight in a population of young military personnel. Health Psychology; 17: 454-458

[28] Alkherayf F, Agbi C (2009). Cigarette smoking and chronic low back pain in the adult population. Clinical and investigative medicine. Medecine clinique et experimentale; 32(5):360-7

[29] Leboeuf-Yde C, Kyvik K O, Bruun N H (1998). Low back pain and lifestyle. Part I: Smoking. Information from a population-based sample of 29,424 twins. Spine; 23(20): 2207-13.

[30] Jamison RN, Stetson BA, Parris WCV (1991). The relationship between cigarette smoking and chronic low back pain. Addict Behav; 16: 103-110 